\title{
Corrigendum: Sediments as a Source of Iron, Manganese, Cobalt and Nickel to Continental Shelf Waters (Louisiana, Gulf of Mexico)
}

\author{
Wytze K. Lenstra ${ }^{1 *}$, Niels A. G. M. van Helmond ${ }^{1}$, Olga M. Żygadłowska ${ }^{1}$, \\ Roosmarijn van Zummeren ${ }^{1}$, Rob Witbaard ${ }^{2}$ and Caroline P. Slomp ${ }^{1}$ \\ ${ }^{1}$ Department of Earth Sciences - Geochemistry, Utrecht University, Utrecht, Netherlands, ${ }^{2}$ Department of Estuarine and \\ Delta Systems, NIOZ, Netherlands Institute for Sea Research, Utrecht University, Utrecht, Netherlands
}

Keywords: bio-essential, benthic flux, organic matter, trace metals, lateral transport, GEOTRACES

OPEN ACCESS

Approved by: Frontiers Editorial Office, Frontiers Media SA, Switzerland

*Correspondence: Wytze K. Lenstra w.k.lenstra@uu.n

Specialty section

This article was submitted to Marine Biogeochemistry,

a section of the journal Frontiers in Marine Science

Received: 31 January 2022 Accepted: 31 January 2022 Published: 22 February 2022

Citation: Lenstra WK, van Helmond NAGM, Żygadłowska OM, van Zummeren $R$,

Witbaard $R$ and Slomp CP (2022) Corrigendum: Sediments as a Source of Iron, Manganese, Cobalt and Nickel to Continental Shelf Waters (Louisiana, Gulf of Mexico). Front. Mar. Sci. 9:866460 doi: 10.3389/fmars.2022.866460

\section{A Corrigendum on}

Sediments as a Source of Iron, Manganese, Cobalt and Nickel to Continental Shelf Waters (Louisiana, Gulf of Mexico)

by Lenstra, W. K., van Helmond, N. A. G. M., Zygadtowska, O. M., van Zummeren, R., Witbaard, R., and Slomp, C. P. (2022). Front. Mar. Sci. 9:811953. doi: 10.3389/fmars.2022.811953

In the original article, the support by the Netherlands Initiative Changing Oceans Program (NICO) was not mentioned in the acknowledgments.

The corrected Acknowledgments are shown below:

"We thank the captain, crew, technicians, (co-)chief scientists D. Rush and Z. Erdem and all other scientists aboard R/V Pelagia during cruise 64PE434 of the Netherlands Initiative Changing Oceans Program (NICO) in March 2018, for their assistance. We also thank H. de Waard, C. Mulder, M. Séguret, and A. van Dijk for analytical assistance in Utrecht."

The authors apologize for this error and state that this does not change the scientific conclusions of the article in any way. The original article has been updated.

Publisher's Note: All claims expressed in this article are solely those of the authors and do not necessarily represent those of their affiliated organizations, or those of the publisher, the editors and the reviewers. Any product that may be evaluated in this article, or claim that may be made by its manufacturer, is not guaranteed or endorsed by the publisher.

Copyright (c) 2022 Lenstra, van Helmond, Żygadłowska, van Zummeren, Witbaard and Slomp. This is an open-access article distributed under the terms of the Creative Commons Attribution License (CC BY). The use, distribution or reproduction in other forums is permitted, provided the original author(s) and the copyright owner(s) are credited and that the original publication in this journal is cited, in accordance with accepted academic practice. No use, distribution or reproduction is permitted which does not comply with these terms. 